\title{
Pressure Flammability Thresholds of Selected Aerospace Materials
}

\author{
David B. Hirsch ${ }^{1}$, James H. Williams ${ }^{2}$, Susana A. Harper ${ }^{3}$, Harold D. Beeson ${ }^{4}$ \\ NASA White Sands Test Facility, Las Cruces, New Mexico, 88004 \\ Gary A. Ruff ${ }^{5}$ \\ NASA John H. Glenn Research Center, Cleveland, $\mathrm{OH}, 44135$ \\ and \\ Michael D. Pedley ${ }^{6}$ \\ NASA Lyndon B. Johnson Space Center, Houston, TX, 77058
}

\begin{abstract}
I. Abstract
A test program was performed to determine the highest pressure in oxygen where materials used in the planned NASA Constellation Program Orion Crew Exploration Vehicle (CEV) Crew Module (CM) would not propagate a flame if an ignition source was present. The test methodology used was similar to that previously used to determine the maximum oxygen concentration (MOC) at which self-extinguishment occurs under constant total pressure conditions. An upward limiting pressure index (ULPI) was determined, where approximately 50 percent of the materials self-extinguish in a given environment. Following this, the maximum total pressure (MTP) was identified; where all samples tested (at least five) self-extinguished following the NASA-STD-6001.A Test 1 burn length criteria. The results obtained on seven materials indicate that the non-metallic materials become flammable in oxygen between 0.4 and 0.9 psia.
\end{abstract}

\section{Introduction}

The Environmental Control and Life Support Systems (ECLSS) of the Crew Exploration Vehicle (CEV) Crew Module $(\mathrm{CM})$ is designed for a leak rate equivalent to a $1 / 4-\mathrm{in}$. hole to maintain a cabin pressure of 8 psia for one hour, during which the astronauts would don their space suits. The crew would then breathe 100 percent oxygen from the space suit oxygen supply while the cabin is allowed to depressurize towards vacuum. Ultimately, the only gas in the $\mathrm{CM}$ cabin would be oxygen at near vacuum pressures from suit leakage. The concern is that cabin materials might be more flammable in oxygen at near vacuum pressures than in the CEV cabin materials certification environment of 30 percent oxygen at 10.2 psia. Therefore, this program was conducted to determine the highest pressure in nearly 100 percent oxygen at which typical spacecraft materials are still self-extinguishing.

${ }^{1}$ Supervisor, Materials Components Testing, NASA Laboratories Department, WS-803, NASA White Sands Test Facility, Las Cruces, New Mexico, 88004

${ }^{2}$ Project Manager, NASA Laboratories Department WS-803, NASA White Sands Test Facility, Las Cruces, New Mexico, 88004

3 Project Manager, NASA Laboratories Department WS-803, NASA White Sands Test Facility, Las Cruces, New Mexico, 88004

${ }^{4}$ Office Chief, NASA Laboratories Office, WS-201, NASA White Sands Test Facility, Las Cruces, New Mexico, 88004

${ }^{5}$ Physical Scientist, 77:128, NASA John H. Glenn Research Center, Cleveland, OH, 44135

${ }^{6}$ Materials Engineer, JSC: ES411, NASA Lyndon B. Johnson Space Center, Houston, TX, 77058 


\section{Experimental Apparatus}

The materials evaluated included plastics (polysulfone and a polyvinylchloride/polymethylmethacrylate alloy), an epoxy/fiberglass laminate, an aramid fabric, films (polyetherimide and polyethylene terephtalate), and a polyimide foam. These are summarized in Table 1 . All samples were 2.5 -in. wide and 6-in. long. ${ }^{*}$ The Nomex ${ }^{\circledR \dagger}$ samples were tested as a single layer with a double-rolled hem on the bottom and side edges.

The equipment used and the experimental approach were similar to previous experiments. ${ }^{1}$

Pressure flammability threshold tests were conducted in a quiescent environment in a closed 1400-L flammability chamber connected to vacuum, oxygen, and nitrogen supplies. The testing was conducted in 99.8 percent oxygen, sequentially following the "up-and-down method for small samples" and using a step size of $0.1 \mathrm{psi}^{2}{ }^{2}$ The NASA-STD-6001 Test $1^{3}$ burn length criterion was used; a sample was considered self-extinguishing if its burn length was less than 6 in. The upward flammability limiting pressure indices (ULPIs) were evaluated statistically; the ULPI represents the total pressure at which a material passes the NASA-STD-6001 Test 1 burn length criteria approximately half the time. The maximum total pressures (MTPs) that consistently resulted in self-extinguishment, i.e., where all samples (at least five) pass the Test 1 burn length criterion, were also determined.

To determine its suitability, the ignitibility of the standard chemical igniter used in NASA flammability tests under low pressure conditions was investigated. In 99.8 percent oxygen, the chemical igniter had an ULPI of 0.783 psia and an MTP of $0.7 \mathrm{psia}$. Since testing needed to be conducted at pressures below $0.7 \mathrm{psia}$, a hot-wire ignition source was used instead. The ignition source consisted of a 6-in. long 20 AWG Ni Chrome wire wound into four coils oriented horizontally with two coils touching the bottom of the sample on each side. A 13.7 A current was applied and the igniter coil was maintained red-hot for approximately $25 \mathrm{~s}$.

\section{Results and Discussion}

The data obtained are summarized in Table 2. For the materials tested, the flammability pressure threshold was in the range of 0.4 to 0.9 psia. The material with the lowest MOC at 10.2 psia (Melinex ${ }^{\circledR \ddagger} 515$ ) also had the lowest MTP. Otherwise, for the materials tested (which had MOCs in the range of 24 to 32 at 10.2 psia), there was no correlation between the MOC and MTP. The results show that CEV CM materials may be flammable in oxygen at pressures as low as $0.4 \mathrm{psia}$ and that the pressure should be kept below 0.4 psia to ensure they are still selfextinguishing. Although no data existed previously, this pressure threshold is appreciably lower than had been expected based on general testing experience, including the failure of the standard chemical igniter to burn below $0.7 \mathrm{psia}$.

\section{CONCLUSIONS AND RECOMMENDATIONS}

Parametric flammability thresholds other than oxygen concentration can be determined with the methodology proposed for evaluating the maximum oxygen concentration (MOC) when extinguishment occurs under given conditions. ${ }^{1}$ In this case, a pressure threshold in 99.8 percent oxygen was determined by the methodology and found to be 0.4 to 0.9 psia for typical spacecraft materials. Correlation of flammability thresholds obtained with chemical, hot wire, and other ignition sources will be conducted to provide recommendations for using alternate ignition sources to evaluate flammability of aerospace materials.

\section{Acknowledgments}

The authors would like to acknowledge the support provided by NASA WSTF Standard Materials Testing Branch: test coordination (Gary Peyton), sample preparation (Horacio Perez, Randy Rodriguez, and Steve Crowl) and testing (Sam Motto, Steve Bailey, Fred Juarez, and Joe Sellers).

* NASA-STD-6001.A Test 1 uses a 12-in. long sample. Since insufficient material was available for all samples to be 12-in. long, 6-in. samples were used, which won't impact the value of MTP. At the MTP, none of the samples burned more than 1-in.

${ }^{\dagger}$ Nomex $^{\circledR}$ is a registered trademark of E. I. du Pont de Nemours and Company, Wilmington, Delaware.

$\mp$ Meline ${ }^{\circledR}$ is a registered trademark of Imperial Chemical Industries Limited Corporation, Great Britain Imperial Chemical House, London, England. 


\section{Contact}

David Hirsch

NASA JSC White Sands Test Facility

P.O. Box 20

Las Cruces, New Mexico 88004

Email: david.b.hirsch@nasa.gov

\section{Notes}

*Any use of trade names in this publication is for descriptive purposes only and does not imply endorsement by the U.S. Government. 


\section{References}

${ }^{1}$ Hirsch, D.B. and Beeson, H.D., "Test Method to Determine Flammability of Aerospace Materials", Journal of Testing and Evaluation, JTEVA, Vol. 30, No. 2, March 2002, pp. 156-159.

${ }^{2}$ Dixon, W., "Up-and-Down Method for Small Samples", Journal of American Statistical Association, Vol. 60, 1965, pp. 967-970.

${ }^{3}$ NASA. Flammability, Offgassing, and Compatibility Requirements and Test Procedures, NASA-STD-(I)6001B, Test 1. NASA, Washington, DC (April 21, 2010). 


\begin{tabular}{|c|c|c|c|}
\hline $\begin{array}{c}\text { Generic or Trade } \\
\text { Name }\end{array}$ & Acronym & Chemical Name or Composition & Additional Material Information \\
\hline $\mathrm{Udel}^{\circledR \mathrm{Ba}} \mathrm{P} 1700$ & PSU & polysulfone & $\begin{array}{l}\text { plastic; Westlake Plastics; } 0.06 \text { in. } \\
\text { thick }\end{array}$ \\
\hline Kydex $^{\circledR b} 100$ & $\begin{array}{l}\text { PVC }+ \\
\text { PMMA }\end{array}$ & $\begin{array}{l}\text { polyvinylchloride and } \\
\text { polymethylmethacrylate alloy }\end{array}$ & $\begin{array}{l}\text { plastic; Rohm \& Haas Co.; } 0.05 \text { in. } \\
\text { thick }\end{array}$ \\
\hline Melinex $^{\circledR C} 515$ & PET & polyethylene terephtalate & $\begin{array}{l}\text { film; DuPont Teijin Films; } 0.005 \text { in. } \\
\text { thick }\end{array}$ \\
\hline Epoxy/glass & - & Epoxy/fiberglass & $\begin{array}{l}\text { laminate; NEMA G-11, H-23842; } \\
\text { Westinghouse; } 0.06 \text { in. thick }\end{array}$ \\
\hline Solimide ${ }^{\circledR \mathrm{d}}$ TA-301 & PI & polyimide & foam; Inspec Foams; 0.12 in. thick \\
\hline Nomex ${ }^{\circledR e}$ HT90-40 & PPTA & aramid & $\begin{array}{l}\text { fabric; Stern \& Stern Industries, Inc.; } \\
0.013 \text { in. thick }\end{array}$ \\
\hline Ultem $^{\circledR f} 1000$ & PEI & polyetherimide & $\begin{array}{l}\text { film; Tekra Corp. P/N DLI1648; } 0.01 \\
\text { in. thick }\end{array}$ \\
\hline \multicolumn{4}{|c|}{ Udel ${ }^{\circledR}$ is a registered trademark of Union Carbide Corporation, New York City, New York. } \\
\hline \multicolumn{4}{|c|}{ Kydex ${ }^{\circledR}$ is a registered trademark of Kleerdex Company, Mount Laurel, New Jersey. } \\
\hline \multicolumn{4}{|c|}{ Meline ${ }^{\otimes}$ is a registered trademark of Imperial Chemical Industries Limited Corporation, Great Britain Imperial Chemical House, } \\
\hline \multicolumn{4}{|c|}{ Solimide ${ }^{\mathbb{E}}$ is a registered trademark of Evonik Foams, Inc, Allen, Texas. } \\
\hline \multicolumn{4}{|c|}{ Nomex ${ }^{\circledR}$ is a registered trademark of E.I. du Pont de Nemours and Company, Wilmington, Delaware } \\
\hline \multicolumn{4}{|c|}{ f Ultem $^{\circledR}$ is a registered trademark of General Electric Company, Pittsfield, Massachusetts } \\
\hline
\end{tabular}

Table 1. Selected polymeric materials evaluated in this study.

\begin{tabular}{lcccc}
\hline \multicolumn{1}{c}{ Material } & ULPI $^{\text {a }}$ & MTP $^{\mathbf{a}}$ & ULOI $^{\mathbf{b}}$ & MOC $^{\mathbf{b}}$ \\
\hline Epoxy/glass & 0.9 & 0.8 & 28.6 & 24 \\
Udel P1700 & 1.0 & 0.9 & 31.7 & 29 \\
Kydex 100 & 1.8 & 0.6 & 33.5 & 32 \\
Solimide TA-301 & 0.7 & 0.5 & 29.3 & 28 \\
Melinex 515 & 0.9 & 0.4 & 21.2 & 20 \\
Nomex HT90-40 & 0.6 & 0.5 & 28.5 & 25 \\
Ultem 1000 & 1.5 & 0.9 & 26.5 & 24 \\
\hline a ULPIs and MTPs have units of psia and were determined in 99.8\% \\
$\quad$ oxygen \\
bLOIs and MOCs have units of \% oxygen by volume and were \\
$\quad$ determined at 10.2 psia \\
\hline
\end{tabular}

Table 2. Pressure and oxygen concentration flammability limits for selected materials. 